\title{
Verbo-nominalne kolokacije kao periferni pojam u hrvatskim rječnicima
}

Sažetak: U članku se obrađuje problem perifernog pojavljivanja kolokacija u općim jednojezičnim rječnicima hrvatskoga standardnoga jezika. Nakon analize vidljivo je da rječnici i jezični portali ne bilježe kolokacije kao posebne leksikografske jedinice. Kolokacije se pojavljuju samo u natuknicama pojedinih leksema koji tvore određenu kolokaciju, što također nije konzekventno, jer ne postoji sustavno provedeno pravilo o tome bi li kolokacija trebala biti navedena uz kolokator ili kolokat. Odsutnost određenih pravila za bilježenje kolokacija problem je za osobe koje uče hrvatski jezik kao strani i za prevoditelje koji trebaju brzo naći značenje traženog jezičnog problema. Problem bilježenja kolokacija može se riješiti izdavanjem kolokacijskog rječnika hrvatskoga jezika u digitalnom ili tiskanom obliku.

Ključne riječi: kolokacije, natuknica, hrvatski rječnici, hrvatski standardni jezik, leksikografija

Problem leksikografskog opisa kolokacija u hrvatskim leksikografskim istraživanjima prisutan je već neko vrijeme. Na kolokacije kao višečlane jezične jedinice ne odnose se ustaljene definicije i uzori koje se upotrebljava za uređivanje rječničkih natuknica, posebno u jednojezičnim rječnicima standardnog jezika; a tek malo drugačije predstavlja se ova situacija u specijaliziranim rječnicima (npr. pravopisnim, frazeološkim i rječnicima pojedinih struka). Višerječne strukture, kakvima se smatra kolokacije, kao punopravne natuknice pojavljuju se samo u frazeološkim rječnicima zbog toga što istraživači u kolokacijama češće prepoznaju frazeologizme nego nestalne jezične jedinice kao npr. u engleskom jeziku, u kojem se kolokacije grupira u posebne kolokacijske rječnike. 
Cilj je ovog rada pokazati način prezentacije kolokacija u jednojezičnim hrvatskim rječnicima izdanima nakon 1990. godine. Analiza je provedena u tiskanim i digitalnim izdanjima, u kojima se - bez obzira na mogućnost prikupljanja i objavljivanja više podataka nego u tiskanim izdanjima - nije mnogo promijenilo. Pregledani su sljedeći tiskani rječnici: Rječnik hrvatskoga jezika Vladimira Anića, Zagreb 1991. (RHJA) s novijim izdanjima, Veliki rječnik hrvatskoga standardnoga jezika (više autora), Zagreb 2015. (VRHSJ) i digitalni rječnici: Hrvatski jezični portal (HJP), Hrvatski terminološki portal (HTP), aplikacija Školske knjige Rječnici.hr (R.hr) - kao baze koje prikupljaju podatke iz različitih rječničkih korpusa trenutačno dostupnih u Hrvatskoj. Analiza je provedena na temelju usporedbe jesu li u navedenim rječnicima prisutne odabrane verbo-nominalne kolokacije koje su najučestalije u hrvatskom jezičnom korpusu (HrWac) - s faktorom pojavnica iznad 10: postavljati pitanja (frekvencija u korpusu - 38472), doći na vrijeme (21443), voditi računa (20536), dobiti odgovor (17563), vidjeti priliku/e (14394), padati na pamet (13395), dati odgovor (13047), nositi ime (11433), postići dogovor (10681), voditi brigu (10515).

Odabir razdoblja iz kojega potječu istraživani rječnici nije slučajan jer se baš potkraj 20. stoljeća počelo istraživati kolokacije u hrvatskom jeziku. Poticaj su bila istraživanja koja je vodio Vladimir Ivir ${ }^{1}$, a tada je ujedno i počelo zanimanje za ovu jezičnu pojavu - prvo na razini dvaju jezika, engleskog i hrvatskog, a poslije samo u hrvatskom jeziku. Od trenutka kada se počelo istraživati kolokacije u engleskom jeziku, 50-ih godina 20. stoljeća u istraživanjima Johna Ruperta Firtha, koji 1957. prvi put upotrebljava pojam kolokacija u svojoj knjizi Modes of Mea$n_{\text {ning }}^{2}$, i lingvisti iz drugih zemalja počeli su tražiti i opisivati višerječne jezične strukture. Tada se, međutim, tvrdilo da se kolokacije u drugim jezicima - osim u engleskom - pojavljuju jako rijetko; zbog čega postoji problem opisa kolokacija, npr. u slavenskim jezicima, te se pokušava povezati istraživanje i opis ovih struktura $\mathrm{s}$ frazeologizmima. Zajedničko je kolokacijama i frazemima to što je njihovo značenje utvrđeno u svijesti izvornih govornika i u objema strukturama postoji stabilna veza između leksema te veoma često ne postoji mogućnost promjene pojedinih elemenata. Različito je, međutim, to što kolokacije mogu imati svoje jednorječne sinonimične ekvivalente u hrvatskom jeziku, ali i u stranim jezicima; kad gledamo iz prevoditeljske perspektive, a za

\footnotetext{
${ }^{1}$ Vladimir Ivir, „Kolokacije i leksičko značenje,“ Filologija, br. 20-21 (1992/1993): 181-189.

2 John Rupert Firth, Modes of Meaning (Oxford: Oxford University Press, 1957), 190-215.
} 
razliku od nekih frazema, kolokacije nisu neprevodive. Problem točnih ekvivalenata čest je jer se kolokacije i jednorječne ekvivalente može naći u različitim funkcionalnim stilovima, ali su one najčešće u različitom kontekstu ili značenju i nije moguća potpuna ekvivalencija. ${ }^{3}$

Frazemi su možda duže obrađivani u leksikografiji, ali također postoji probem njihova opisa u jednojezičnim rječnicima. U slučaju frazema situacija je riješena jer su dostupni posebni frazeološki rječnici i u natuknicama su leksemi koji se po semantici vežu uz frazem zabilježeni zajedno s njim. S druge strane, u općim rječnicima nije moguće naći frazeme kao posebne leksikografske jedinice. U tom bi slučaju mnogo podataka trebalo stalno ponavljati, što bi rezultiralo manjkom mjesta za lekseme koji ne tvore nikakve frazeme. Dakle, posebni su rječnici optimalna mogućnost rješenja problema i u slučaju kolokacija. Od svih navedenih priručnika samo Kolokacijska baza hrvatskoga jezika (http:/ihjj.hr/kolokacije) daje mogućnost pretraživanja po cijelim konstrukcijama i prikazuje podatke o višečlanim jezičnim jedinicama te se može smatrati stručnim portalom za pretraživanje pojednih kolokacija neovisno o vrsti i značenju upotrebljavanih riječi.

Verbo-nominalne kolokacije su skupina sveza riječi koje su najfrekventnije u jezičnom korpusu. U jednojezičnim rječnicima hrvatskog jezika teško je naći ove strukture jer ih natuknice vrlo rijetko bilježe, čak i kao podnatuknice ili primjere uporabe. ${ }^{4}$ Ova situacija nije praktična iz perspektive izvornih govornika jezika koji se koriste rječnikom da nađu detaljnije informacije koje se tiču uporabe, strukture ili sklonidbe tražene strukture, ali posebno je to nepraktično osobama koje se služe hrvatskim jezikom kao stranim - studentima i prevoditeljima. Odsutnost kolokacija u rječnicima, čak i u podnatuknicama, razlog je zbog kojeg se veoma teško može naći ispravno značenje i sintaktička uporaba tražene jezične strukture. Kolokacije se ne tvore po intuitivnoj shemi, dakle nemoguće je da će točnu kolokaciju ispravno upotrijebiti osoba koja nije izvorni govornik jezika prije negoli je nađe i shvati kako i u kojem kontekstu se može njome služiti. To je ujedno i razlog zbog kojeg je izražavanje u kojem se ne upotrebljavaju višerječne strukture siromašnije i neprirodno, a ako se elementi kolokacije pogrešno povežu, ono postaje neispravno i nerazumljivo.

Iako su u analizi pregledani različiti rječnici, vidljivo je da su u njima kolokacije - i to ne samo verbo-nominalne - periferna pojava.

\footnotetext{
${ }^{3}$ Goranka Blagus Bartolec, ,Glagolske kolokacije u administrativnome funkcionalnom stilu,“ Rasprave Instituta za hrvatski jezik i jezikoslovlje, vol. 43, br. 2 (2017): 303.

${ }^{4}$ Blagus Bartolec, „Glagolske kolokacije,“ 287.
} 
Ako se uopće nalaze u rječnicima, tamo se jako rijetko javljaju - kao dodatak glavnim natuknicama, a predstavljene su kao frazeologizmi. Nije to rijedak slučaj ni na internetskim portalima, gdje se, unatoč tomu što ne postoji ograničenje u obimu izdane knjige, kolokacije ne pojavljuju češće. Jedina je iznimka Hrvatski terminološki portal (http:// nazivlje.hr/english) koji donosi više primjera za kolokacije, a prikuplja natuknice iz različitih rječnika, npr. s portala Struna (http://struna.ihjj. hr/page/o-struni) ili iz strukovnih rječnika Leksikografskog zavoda Miroslav Krleža. Većina kolokacija prikupljenih na portalu ipak se sastoji od nekih drugih leksičkih skupina jer su termini često nominalno-adjektivne kolokacije ili rjeđe nominalno-nominalne, dok se u tehničkoj terminologiji najrjeđe pojavljuju verbo-nominalne kolokacijske sveze (sasvim je drugačija čestotnost verbo-nominalnih kolokacija u zakonskoj terminologiji i administrativnom funkcionalnom stilu ${ }^{5}$, gdje su najčešće $u$ hrvatskom standardnom jeziku).

Problem pretraživanja rječnika u potrazi za kolokacijama, bez obzira na to je li riječ o digitalnom ili tiskanom izdanju, nekonzekventno je bilježenje ovih višerječnih jedinica: neke od njih mogu se naći uz natuknicu koja definira imenicu iz tražene kolokacije, a drugi put uz glagol (tiče se to također i drugih vrsta riječi). Nekonzekventno bilježenje kolokacija uz kolokator ili uz kolokat ometa potragu, koja čak može završiti neuspjehom, a ujedno produžava vrijeme rada na tekstu (što je bitno za prevoditelje). Stavljanje kolokacija uz kolokat, tj. uz nositelja značenja, može imati više smisla; zbog toga se ponekad leksikografska praksa temelji na ovom pravilu i kolokacije nalazimo uz imenicu (barem u verbo-nominalnim kolokacijama) jer je imenica nositelj značenja čitavog višerječnog sklopa. Ipak, nije to opće pravilo u rječnicima. Takvo bilježenje kolokacija pogrešno je opravdano time da kolokacija mora imati svoj jednorječni ekvivalent, dakle da ima sinonimično značenje s određenim leksemom. U slučaju verbo-nominalnih kolokacija leksem uz koji se bilježi kolokaciju po ekvivalentu je glagol. Ewa Białek tvrdi da su sinonimični odnosi između višerječne i jednorječne jedinice veoma složeni i da ne može biti riječi o potpunoj sinonimičnosti. ${ }^{6}$ Zbog toga je kolokacije dobro prikazivati kao odvojene natuknice koje definiraju određeno značenje i strukturu.

Kako je već spomenuto, dodatni materijal za analizu rječnika bili su navedeni primjeri kolokacija, koji u korpusu HrWac imaju veliku

\footnotetext{
${ }^{5}$ Blagus Bartolec, „Glagolske kolokacije,“ 289.

${ }^{6}$ Ewa Białek, „Kolokacja i wyraz - uwagi o relacji synonimii oraz ekwiwalencji,“ Annales Universitatis Marie Curie-Skłodowska Lublin - Polonia, vol. XXXI (2013): 191.
} 
frekvenciju, što znači i visok postotak uporabe među izvornim govornicima jezika. Nažalost, to nije imalo odjeka u jednojezičnim rječnicima i na jezičnim portalima hrvatskog jezika.

\begin{tabular}{|l|c|c|c|c|c|}
\hline \multicolumn{1}{|c|}{ Rječnik } & $\begin{array}{c}\text { Kolokacija } \\
\text { (samostalno) }\end{array}$ & Uz imenicu & Uz glagol & U definiciji & Odsutno \\
\hline RHJA & 0 & 2 & 1 & 3 & 7 \\
\hline VRHSJ & 0 & 2 & 5 & 5 & 5 \\
\hline HJP & 0 & 5 & 2 & 5 & 5 \\
\hline HTP & 0 & 0 & 0 & 0 & 10 \\
\hline R.hr & 0 & 1 & 1 & 2 & 8 \\
\hline
\end{tabular}

Tablica 1. Kolokacije u rječnicima i na jezičnim portalima

Rječnik Vladimira Anića iz 1991. i njegova novija izdanja nastaju u razdoblju kada u hrvatskoj lingvistici pojam i istraživanje pojavnosti kolokacija nisu bili toliko rasprostranjeni i zbog toga se u ovom rječniku pojavljuje najmanji postotak analiziranih kolokacija. Iz cijele grupe od deset analiziranih struktura u rječniku nalazimo samo tri, od kojih se dvije pojavljuju uz imenicu i jedna uz glagol kao komponenta kolokacije, a sve su određene kao frazeologizmi.

$\mathrm{Na}$ Hrvatskom jezičnom portalu, koji okuplja korpuse ranije izdanih rječnika: Rječnik hrvatskoga jezika (V. Anić, I. izdanje 1991, II. izdanje 1994. i III. izdanje 1998), Veliki rječnik hrvatskoga jezika (V. Anić, 2003. priredila Ljiljana Jojić), Rječnik stranih riječi (Anić - Goldstein, I. izdanje 1998, II. izdanje 2000) i Hrvatski enciklopedijski rječnik (uređivački odbor: prof. dr. Vladimir Anić, prof. dr. Ranko Matasović, prof. dr. Ivo Pranjković, dr. Dunja Brozović Rončević, prof. dr. Ivo Goldstein, Slavko Goldstein, mr. Ljiljana Jojić, Ljiljana Cikota; 2003), i dalje postoji problem s načelima bilježenja kolokacija. Može ih se naći i uz kolokator i uz kolokat, ali ima ih više nego u ranijim izdanjima rječnika. Kolokacije se mogu naći u podnatuknicama i primjerima uporabe, nisu točno prikazane kao kolokacije nego kao sintagme, ali što se tiče broja kolokacija i njihovih definicija, na $H J P$-u ih se može naći najviše. Iako ih se ne može naći upisujući cijeli izraz u tražilicu, jer je pretraga moguća samo po jednorječnim pojmovima, ipak su prisutne uz glavne natuknice.

Hrvatski terminološki portal, međutim, ne bilježi ni jednu od navedenih kolokacija. Ova činjenica ne čudi jer istraživane kolokacije nisu termini, ne potječu iz strukovnog, nego iz standardnog jezika. HTP je ipak bitan za jezikoslovce jer samo ovdje se sveze riječi u cjelini mogu 
tražiti putem tražilice, dakle kao višerječne skupine u okviru termina, a to otvara mogućnost potrage za kolokacijama. Kako je već spomenuto, na portalu se nalazi manji postotak verbo-nominalnih kolokacija nego na ostalim analiziranim mjestima, dok je ujedno upravo ovdje najveći postotak kolokacijskih sveza sastavljenih od drugih vrsta riječi u odnosu na ostale hrvatske rječnike i jezične baze podataka. Zahvaljujući strukturnim osobinama termina, koji su često višerječne sveze, na portalu je moguća pretraga kolokacija. Mora se spomenuti da je moguće naći verbo-nominalne kolokacije ako funkcioniraju kao termini.

Aplikacija Školske knjige Rječnici.hr dostupna je za različite mobilne uređaje, a sadrži digitalne verzije hrvatskih jednojezičnih i dvojezičnih rječnika izdavačke kuće Školska knjiga. Nalazimo dosta razlika između digitalnih i tiskanih verzija. Kolokacija nema mnogo, kao ni u Anićevu rječniku, a paradoksalno je što ćemo u tiskanom izdanju Velikog rječnika hrvatskog standardnog jezika naći mnogo više kolokacija nego u aplikaciji. Nadalje, urednici rječnika ne vide jezični potencijal kolokacija i važnu ulogu koju igraju u glotodidaktici te u prevođenju. Kolokacije su u tiskanoj verziji Velikog rječnika najčešće smještene u glagolskim natuknicama i lako ih je pronaći. Ipak, nije to opće pravilo u cijelom rječniku, ali se temelji na tome da je glagol kao baza kolokacija bitan iz strukturne i sintaktičke perspektive. U Velikom rječniku hrvatskog standardnog jezika može se naći i treći način bilježenja kolokacija u natuknici - kao definicija sintetičkih glagolskih ekvivalenata - što nije česta praksa u drugim rječnicima, a temelji se na jednoj od definicija kolokacija koja kaže da su sveze riječi kolokacije kada imaju točan / odgovarajući semantički sintetički ekvivalent. ${ }^{7}$

Vidljiva je ipak mala razlika među rječnicima izdanima potkraj 20. stoljeća i onima izdanima nakon 2010. i na internetu. U glotodidaktici preporučuje se odvajanje kolokacija kao posebnih jezičnih jedinica i zbog toga ih ima nešto više u novijim rječnicima, iako su i dalje objašnjene kao frazeologizmi. Učenje kolokacija veoma je bitno jer se zahvaljujući njima prepoznaje prirodna narav određenog jezika i zbog toga se o njima često govori u kontekstu priručnika za strance i jezičnih vježbi. Nažalost, to još nije toliko popularno u leksikografskoj praksi, koja bi na prvom mjestu trebala bilježiti jezične pojmove teške za učenje, a takvima se mogu smatrati i kolokacije.

\footnotetext{
${ }^{7}$ Mariola Szymczak-Rozlach, Analityczne struktury werbo-nominalne w języku słowackim (Katowice: Wydawnictwo Uniwersytetu Śląskiego, 2010), 8.
} 
Svi podatci navedeni u članku upućuju na sljedeće zaključke:

- o kolokacijama se, kao jezičnoj pojavi, misli periferno: neki istraživači drže da kolokacije nisu glotodidaktički i prevoditeljski problem, poput idioma i frazeologizama, pa prisutnost ovih sveza u općim rječnicima nije potrebna;

- rječnici su građeni po shemi utvrđenoj u tradiciji: kolokacijama kao višečlanim jezičnim jedinicama nema mjesta u rječniku u kojem se definira samo jednorječne lekseme, kolokacije se tamo mogu naći samo kao primjeri uporabe komponenata koje ih tvore ili kao dopune sintetičkim glagolima;

- kolokacije se smatra frazeologizmima: prisutne su u frazeološkim rječnicima i tamo se mogu bilježiti kao posebne natuknice; u općim rječnicima standardnog jezika to nije moguće zbog opće leksikografske koncepcije bilježenja rječnika;

- nedostatak leksikografske svijesti o važnosti navođenja kolokacija u rječniku: poželjno je da se kolokacije nađu u rječnicima u odvojenim natuknicama, a kad to nije moguće - kao dodatak leksemskim definicijama.

Stav prema statusu kolokacija u općim rječnicima hrvatskoga standardnoga jezika počeo se mijenjati pod utjecajem poučavanja engleskoga jezika i engleske glotodidaktičke prakse koja sve više ulazi u poučavanje drugih stranih jezika. Hrvatski lingvisti sve češće se počinju zanimati za kolokacije kao jezični fenomen, i to samo u kontekstu hrvatskoga jezika - baveći se uporabom, funkcioniranjem u sintaksi i mogućnostima pojedinih riječi da stvaraju ustaljene sveze. Sada se govori o tome kako se u jeziku vrlo često pojavljuju analitičke strukture, posebno u standardnom jeziku, što je vidljivo u tome da se upotrebljava više kolokacija, čak i u neslužbenim tekstovima i kolokvijalnom govoru. Ranije su ove strukture najčešće bile pristutne u novinarskom i znanstvenom funkcionalnom stilu jer se zahvaljujući njima mogla postići viša razina preciznosti. Goranka Blagus Bartolec također upućuje na to da $\mathrm{u}$ administrativnom fukcionalnom stilu hrvatskoga jezika ima sve više sveza riječi koje su zakonski i ekonomski termini, ali su po strukturi kolokacije. ${ }^{8}$

S točke gledišta glotodidaktike i prevođenja nije bitno samo značenje kolokacija, dakle natuknica bi također morala sadržavati podatke o njezinoj strukturi i sintaktičkim mogućnostima koje daju upute kori-

\footnotetext{
${ }^{8}$ Blagus Bartolec, ,Glagolske kolokacije,“ 287.
} 
snicima kako se služiti tim konstrukcijama i pomažu u učenju stranog jezika. Današnje tehničke mogućnosti stvaranja digitalnih rječnika i jezičnih internetskih portala pružaju priliku prikupljanja velikih količina podataka koje su potrebne da se pokaže puno informacija u jednoj natuknici. Može se također graditi poveznice među različitim natuknicama kako bi se pokazala sinonimičnost nekih izraza ili različite mogućnosti uporabe. Podatci koji se mogu skupiti u jednoj natuknici, uz metajezičnost, moraju prije svega biti usmjereni na praktični pristup, stoga bi se u natuknicama trebali nalaziti primjeri uporabe, najbolje izvedeni iz korpusa da se može vidjeti stvarna jezična praksa.

Periferni položaj kolokacija u hrvatskim rječnicima određenje leksikografskom općelingvističkom tradicijom i nije problem samo hrvatskog jezika. Slična je situacija i u poljskom jeziku. Engleska je tradicija istraživanja kolokacija duža i temelji se na većoj analitičnosti tog jezika u usporedbi sa slavenskim jezicima. Ako se kolokacije ne mogu naći u natuknicama općih jednojezičnih rječnika, za glotodidaktiku i prevođenje od velike bi koristi bilo sastaviti poseban jednojezični rječnik tih višerječnih struktura, u kojem bi svaka kolokacija, bez obzira na to je li glagolska, imenska ili je pak sastavljena od drugih riječi, bila zabilježena kao posebna natuknica.

\section{Literatura}

Białek, Ewa. „Kolokacja i wyraz - uwagi o relacji synonimii oraz ekwiwalencji.“ Annales Universitatis Marie Curie-Skłodowska Lublin - Polonia, vol. XXXI (2013): 89-104.

Blagus Bartolec, Goranka. „Glagolske kolokacije u administrativnome funkcionalnom stilu.“ Rasprave Instituta za hrvatski jezik i jezikoslovlje, vol. 43, br. 2 (2017): 285-309.

Firth, John Rupert. Modes of Meaning. Oxford: Oxford University Press, 1957.

Ivir, Vladimir. „Kolokacije i leksičko značenje.“ Filologija, br. 20-21 (1992/1993): 181-189.

Szymczak-Rozlach, Mariola. Analityczne struktury werbo-nominalne w języku słowackim. Katowice: Wydawnictwo Uniwersytetu Śląskiego, 2010.

\section{Izvori}

Anić, Vladimir. Rječnik hrvatskoga jezika. Zagreb: Novi Liber, 1991. i novija izdanja.

Hrvatski jezični portal, 2020. (online). http://hjp.znanje.hr/. Pristupljeno: 20. siječnja 2020. 
Hrvatski terminološki portal, 2020. (online). http://nazivlje.hr/. Pristupljeno: 20. siječnja 2020.

Jojić, Ljiljana, Anuška Nakić, Nada Vajs Vinja, Vesna Zečević. Veliki rječnik hrvatskoga standardnoga jezika. Zagreb: Školska knjiga, 2015.

Rječnici.hr Školska knjiga (mobilna aplikacija). Pristupljeno: 20. siječnja 2020.

\section{Verb-Nominal Collocations as a Peripheral Issue in Croatian Dictionaries}

Summary: The aim of the paper is to indicate the status of the peripheral representation of verb-nominal collocations in Croatian monolingual dictionaries. After the analysis, it is evident that dictionaries and language portals do not record collocations as separate lexicographic units. Collocations appear only in the entries of individual lexemes that form a particular collocation, which is also not consistent, as there is no systematically implemented rule as to whether collocation should be listed next to the collocator or collocate. The absence of certain rules for recording collocations is a problem for people learning Croatian as a foreign language and for translators who need to quickly find the meaning of the required language problem. The problem of recording collocations can be solved by publishing a collocation dictionary of the Croatian language in digital or printed form.

Keywords: collocations, dictionary entries, Croatian dictionaries, standard Croatian language, lexicography 